\title{
A Computer Based System for Evaluating the Risk of Contracting Human Immunodeficiency Virus (HIV)
}

\author{
Oguntimilehin A ${ }^{1}$, Sanya. O.A ${ }^{2}$, Abiodun A.I ${ }^{3}$, Babalola G.O ${ }^{4}$. \\ ${ }^{1}$ Department of Computer Science, Afe Babalola University, Ado-Ekiti, Nigeria, ebenabiodun2@yahoo.com
}

Received Date : October 10, 2021 Accepted Date : November 14, 2021 Published Date : December 07, 2021

\begin{abstract}
Human Immunodeficiency Virus (HIV) and Acquired Immunodeficiency Syndrome (AIDS) remain global pandemics. The 2020 statistics released in 2021 showed that about 37.6 million people globally are living with HIV; 1.5 million people became newly infected in 2020 and 690,000 people died from AIDS related cases the same year. A literature search revealed that more than 1.6 million Nigerians have died of HIV/AIDS since the outbreak of the epidemic in 1985 while millions of Nigerians are living with $\mathrm{HIV}$ as of today. Certain factors have contributed to this alarming statistic. One of such is the unwillingness by most persons to undertake an HIV test due to the fear of stigmatization. A simple system that can be of help in evaluating a person's risk of contracting HIV without stigmatization is developed in this work. The system takes into account some behavioural factors, signs and symptoms that suggest a person may be at risk of having or be prone to $\mathrm{HIV}$ and thus makes a prediction of the risk status based on the input supplied. A simple framework was developed with input from medical practitioners based on their wealth of experience. The input was used to derive twenty two (22) questions centered on behavioural factors, signs and symptoms which were designed to be answered by the users during interaction with the system. A simple evaluation takes place using the user's inputs and a predefined set of rules to classify the risk value as one of (Very High, High, Moderate, Low and Not at Risk) with appropriate advice. The system was implemented in Visual Studio Environment using Visual Basic.Net. It is expected that after using the system, users will be encouraged to go for tests where it is recommended. However, it to be noted that this system does not confirm HIV status as only a blood test can do that.
\end{abstract}

Key words : Inference Engine, Prediction, Behavioural Factors, Symptoms, Signs, HIV.

\section{INTRODUCTION}

Human Immunodeficiency Virus (HIV) and AIDS remain global pandemics. By the end of the first decade in the 21st century, approximately 33.3 million people were living with HIV compared to about 26.2 million in 1999, reflecting about 27 per cent increase. High risk factors like unprotected sex, intravenous drug injection, presence of sexually transmitted infections (STIs), multiple sexual partners and substance abuse, early sexual initiation, lack of awareness in relation to HIV and AIDS, heterosexual transmission, poverty, school dropout were among the cited factors that fuel the transmission of HIV [6].

The first two AIDS cases in Nigeria was diagnosed in 1985 and reported in 1986 in Lagos one of which was a young female sex worker aged 13 years from one of the West African countries [19]. The news of this first AIDS case sent panic, doubt and disbelief to the whole nation as AIDS was perceived as the disease of American homosexuals. Some people saw the story about AIDS as a ploy by the Americans to discourage sex and many acronyms, one of which was American Idea for Discouraging Sex emerged at the time. This earlier perceptions, skepticisms and reactions of the Nigerian public towards the 'foreign' AIDS case and HIV/ AIDS in general has been well documented in the introductory part of a doctoral thesis on 'Modelling HIV/AIDS Epidemic in Nigeria' that can be found online [6].

The highest numbers of HIV prevalence were found mostly in Benue, FCT, Anambra, Bayelsa and Akwa Ibom States of the federation. These marked differences in the prevalence rates among these states could be due to a number of factors including but not limited to cultural differences, varying levels of education, religion and differing socioeconomic structures. Indeed, there must be interplay of these factors on HIV/AIDS outcomes in these states [6]. The increased in demand for high-quality medical services coupled with the explosive growth of medical knowledge led to the suggestion that computer programs should be used in assisting physicians and other healthcare providers in discharging their clinical roles such as diagnosis, therapy and treatment[12]. 
Oguntimilehin A et al., International Journal of Science and Advanced Information Technology, 10 (6), November - December 2021, 25 - 29

\section{REVIEW OF RELATED RESEARCH}

In the research by Marya Gwadz et al in [2], it was noted that stigmatization was a primary barrier to initial and continuous HIV testing even among individuals living in high risk areas. They further argued that HIV-related stigma is a major deterrent to a range of HIV-related protective behaviours including disclosure of HIV status, linkage to HIV care, uptake of HIV antiretroviral therapy, and medication adherence, particularly among vulnerable populations that are at the greatest risk for HIV infection. The research also noted that in the context of an under-resourced community, HIV stigma was experienced as emerging from, and being perpetuated by, health care organizations and educational institutions, as well as community members. Participants noted it was "better not to know" one's HIV status, to avoid experiencing HIV-related stigma, which could interact with other stigmatized social identities and threaten vital social relationships, life chances, and resources; and this is very dangerous as it will lead to more people being infected.

In [13], Oguntimilehin et al noted that the internet and information communication technology (ICT) infrastructures are transforming the future of health management. This statement was also earlier stated by Agbonifo et al in [3] where they noted that the use of telecommunication technologies to deliver healthcare service has been dated back to the birth of television and telephone in $19^{\text {th }}$ century. [13] however further noted that the cost of healthcare delivery systems, products and services continue to rise unabated, especially in Nigeria - a developing nation that needs technology driven by Information and Communication Technology (ICT) as an agent of a revolution, which has changed all aspects of society, the way we talk, learn, communicate, buy and sell.

United Nations and World Health Organization made a case in [18] that artificial Intelligence (AI) holds enormous potential for improving the health of millions around the world if ethics and human rights are at the heart of its design, deployment, and use. Further to this, telemedicine and e-health systems have been proposed as a support tool, to monitor and evaluate HIV/AIDS management strategies. In their research in [15], they noted that one of the challenges of access to treatment through anti-retroviral medication is the difficulty of receiving accurate and up-to-date information at the planning level. Information and Communication Technology (ICT) has been used in a number of pilot studies to address this bottleneck by providing an infrastructure for telemedicine and e-health applications; and this was further supported by Maitrayee in [9]. In his research, he noted that technology provides the opportunity and the spur for rethinking a great number of traditional paradigms. Different health resources can be searched through one common index using a single tool. Networking of computers today plays an important role in communication and dissemination of information.

\section{METHODOLOGY}

\subsection{Description of the Simple Predictive Model}

Consultations were made with medical experts; certain factors that can increase the risk of contracting HIV were keenly studied. Also, possible signs and symptoms together with behavioural factors were put into consideration. These were used as input to design the model for predicting the risk of contracting HIV. These risk factors were used to model a simple risk rate predictive system using the signs, symptoms and behavioural factors. Twenty two (22) questions as shown in Table 1 were generated from the combination of the signs, symptoms and behavioural factors as suggested by medical experts. A predetermined set of simple rules was generated to serve as the inference engine of the system based on a simple calculation from the input values.

Table 1: Signs, Symptoms and Behavioural Factors

\begin{tabular}{|c|c|}
\hline $\mathrm{S} / \mathrm{N}$ & Questions \\
\hline 1 & $\begin{array}{l}\text { Have you been experiencing weight loss for more than } \\
\text { a month? }\end{array}$ \\
\hline 2 & $\begin{array}{l}\text { Have you been experiencing fever that is not abating } \\
\text { for more than a month? }\end{array}$ \\
\hline 3 & $\begin{array}{l}\text { Have you been passing watery stool for more than a } \\
\text { month? }\end{array}$ \\
\hline 4 & $\begin{array}{l}\text { Have you experienced cough in resent time for more } \\
\text { than a month? }\end{array}$ \\
\hline 5 & $\begin{array}{l}\text { Have you had itchy body rashes for more than two } \\
\text { months? }\end{array}$ \\
\hline 6 & $\begin{array}{l}\text { Have you had whitish discharges either in your mouth } \\
\text { or vagina? }\end{array}$ \\
\hline 7 & Have you observed painful body swellings? \\
\hline 8 & $\begin{array}{l}\text { Have you experienced boil around the anal region that } \\
\text { is not responsive to antibiotic? }\end{array}$ \\
\hline 9 & Have you ever had unprotected sexual intercourse? \\
\hline 10 & $\begin{array}{l}\text { Do you use lubricants with condoms during sexual } \\
\text { intercourse? }\end{array}$ \\
\hline 11 & Do you have more than one sexual partner? \\
\hline 12 & Are you sexually attracted to the same gender? \\
\hline 13 & $\begin{array}{l}\text { Are you the incentive partner during sexual } \\
\text { intercourses? }\end{array}$ \\
\hline 14 & Do you engage in oral sex? \\
\hline 15 & Do you engage in anal sex? \\
\hline 16 & Do you engage in vaginal sex? \\
\hline 17 & Have you ever engaged in sex in order to get money? \\
\hline 18 & $\begin{array}{l}\text { Have you ever been transfused with blood that is not } \\
\text { safe or from an unknown source? }\end{array}$ \\
\hline 19 & $\begin{array}{l}\text { Have you ever been surgically operated on before } \\
\text { using instrument that was not sterilized? }\end{array}$ \\
\hline 20 & Have you ever been injected with unsterilized needles? \\
\hline 21 & $\begin{array}{l}\text { Have you ever had the course to share needles or sharp } \\
\text { objects with people? }\end{array}$ \\
\hline 22 & $\begin{array}{l}\text { Have you ever had any of these infections e.g } \\
\text { Gonorrhea, Syphilis, Chlamydia Scephis? }\end{array}$ \\
\hline
\end{tabular}




\subsection{Experimental Set Up and Result}

The questions are set up for binary answers, hence a user responses can only either be a YES or a No to each question. The numbers of YES and NO is used to perform the prediction using the simple formula given in Equation1 and the classification range is given in Table 2:

Detection Value $=\frac{\mathrm{N}_{\mathrm{Y}}}{22} * \frac{100}{1} \%$

Where $\mathrm{N}_{\mathrm{Y}}=$ Number of Yes

Table 2: Classification Range

\begin{tabular}{|l|l|}
\hline Range & Classification \\
\hline $80-100 \%$ & Very High \\
\hline $60-79.99 \%$ & High \\
\hline $30-59.99 \%$ & Moderate \\
\hline $1-29.99 \%$ & Low \\
\hline $0 \%$ & Not at Risk \\
\hline
\end{tabular}

\section{Implementation and Discussion of Result}

This research fully takes into consideration the fact that only a blood test at approved designated health care facilities can truly confirm the HIV status of an individual. However, if the subject desires to undertake an evaluation test to know his or her stands, this research work is a good fit for that. The system was implemented in Visual Studio Environment using Visual Basic.Net. Users are expected to lunch the software after a successful installation of the Software set up. The software has five major Graphical User Interfaces (GUIs). They are Front Page or Opening Page, Personal Information pages, Risk Evaluation pages, Result page and a Print Page.

The user provides their information in the Personal Information Page. After the information is successfully provided, the user precedes to the Risk evaluation pages. This is where the twenty two (22) questions are made available to the user. Since the questions require Yes/No answers, the user only has to select either a YES or a NO to respond to each question. After this interaction, a submission is made to the system and the system uses the evaluation formula to access the risk level of the user. The screenshot of the Front Page is shown in Figure 1, Personal Information Page is shown in Figure 2, Risk Evaluation pages are shown in Figures 3 and 4 while HIV Risk Prediction/Result page is shown in Figure 5. Figure 6 is a page which avails the user the opportunity to print the result of the evaluation.

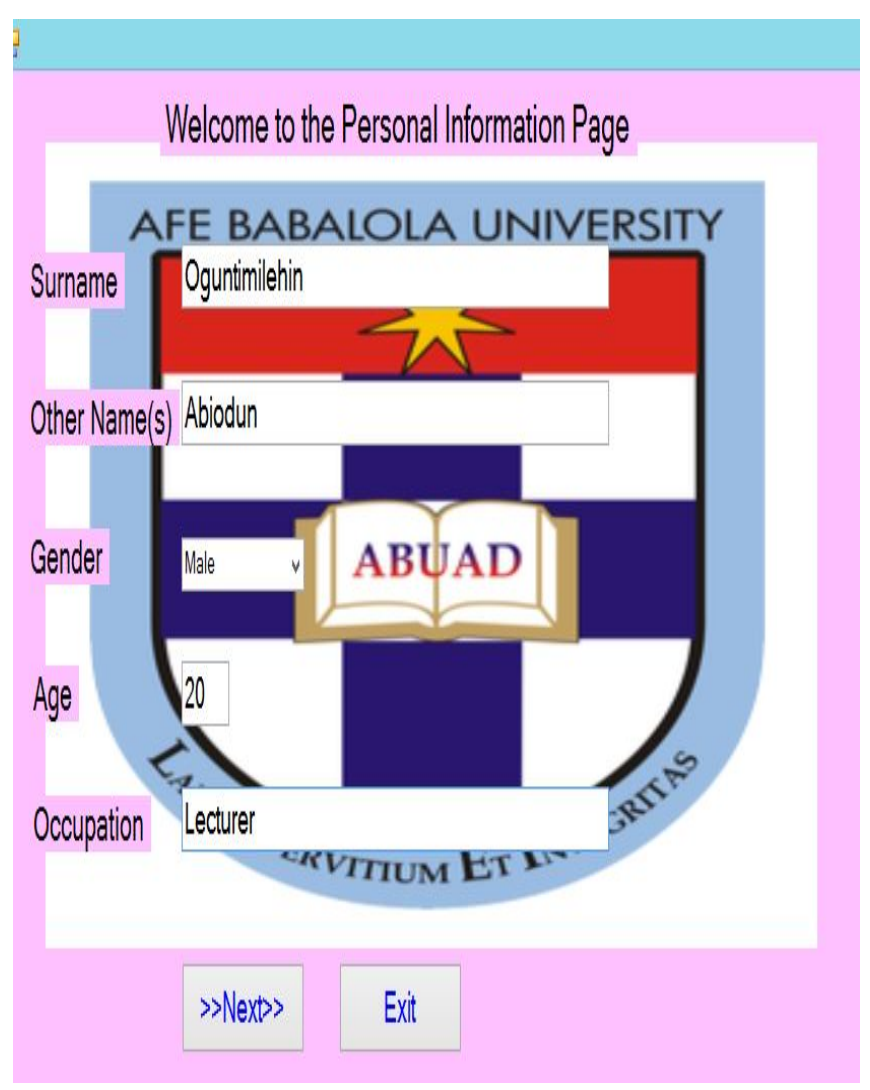

Figure 1: Screenshot of the Front Page.

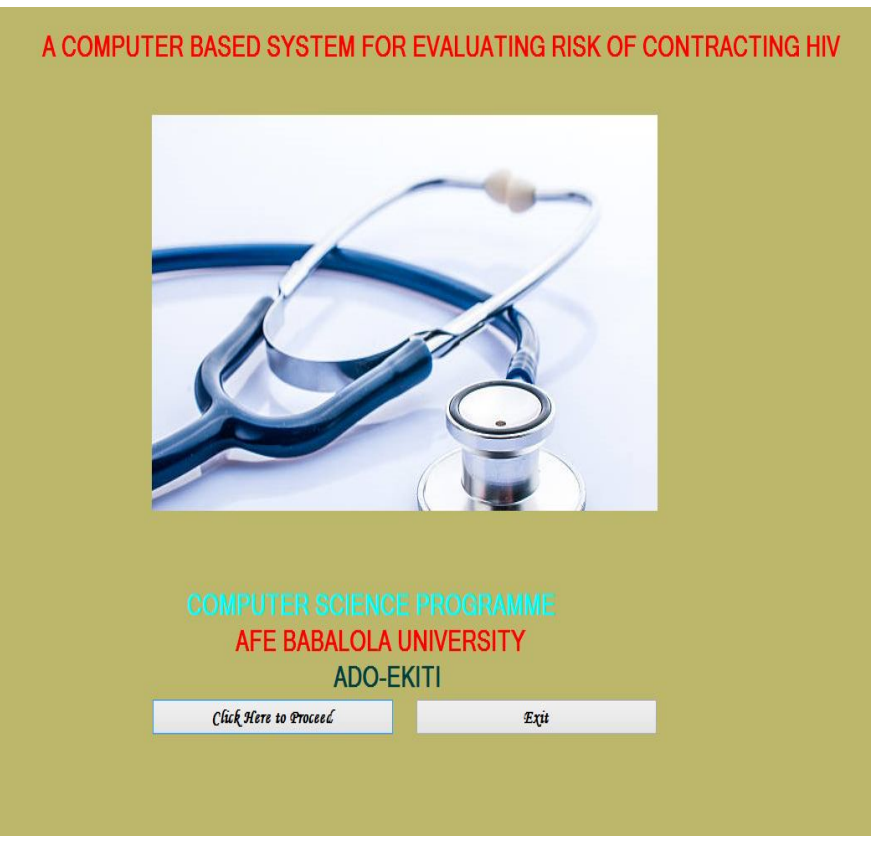

Figure 2: Screenshot of mini Personal Information Page 


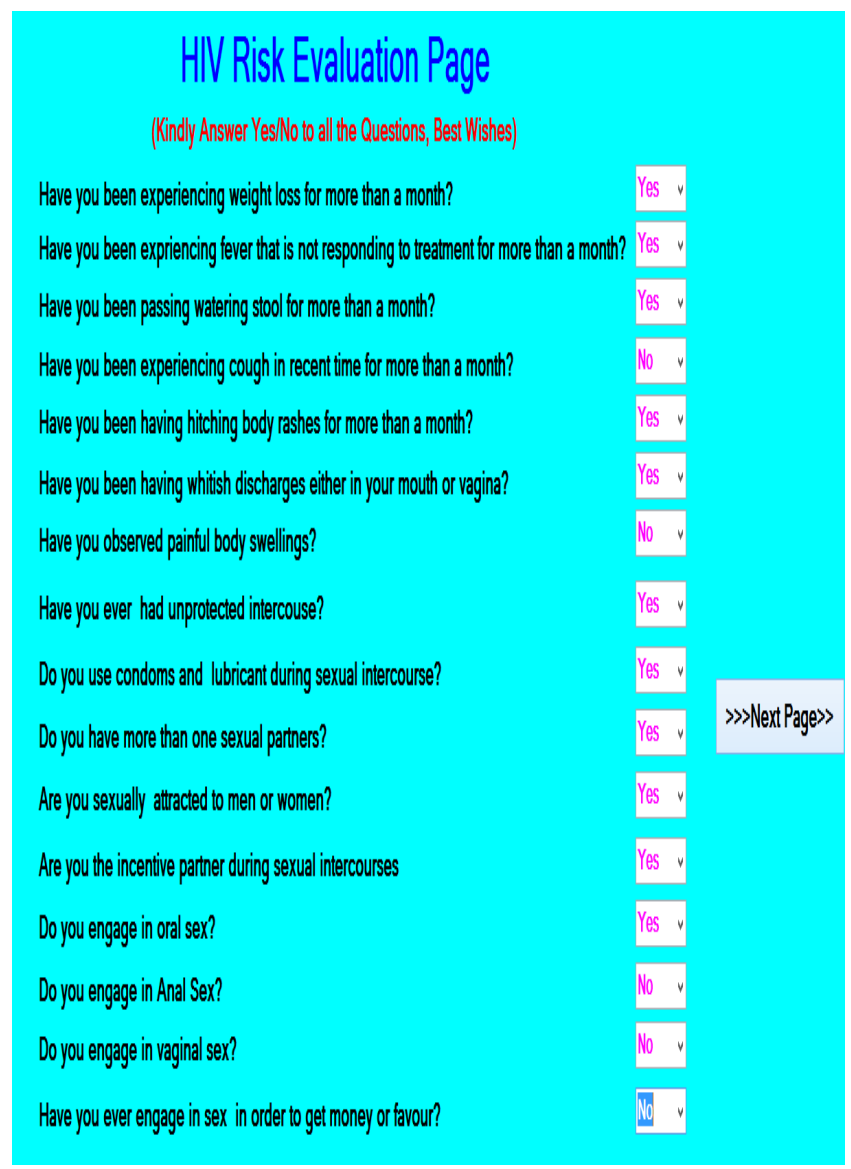

Figure 3 : Screenshot of HIV Risk Evaluation Page 1

\section{HIV Risk Evaluation Page 2}

(Kindly Answer Yes: No to all the Quessions, Best. Wishes)

\begin{tabular}{|c|c|c|}
\hline Have you ever been injected with uns & & No \\
\hline Have you ever had any reason to sha & ler sharp objects with any one? & Yes 。 \\
\hline Have you ever had any of these intec & a, Syphills, Chlamydia Scephis? & No \\
\hline Have you ever been surgically operat & se of sterillzed equipment? & Yes. \\
\hline Have you experienced boil around ar & not responsive to antibiotics? & No \\
\hline Have you ever had blood transfussion & urce? & $\mathrm{NO}$ \\
\hline View Report & Exit & \\
\hline
\end{tabular}

Figure 4: Screenshot of HIV Risk Evaluation Page 2

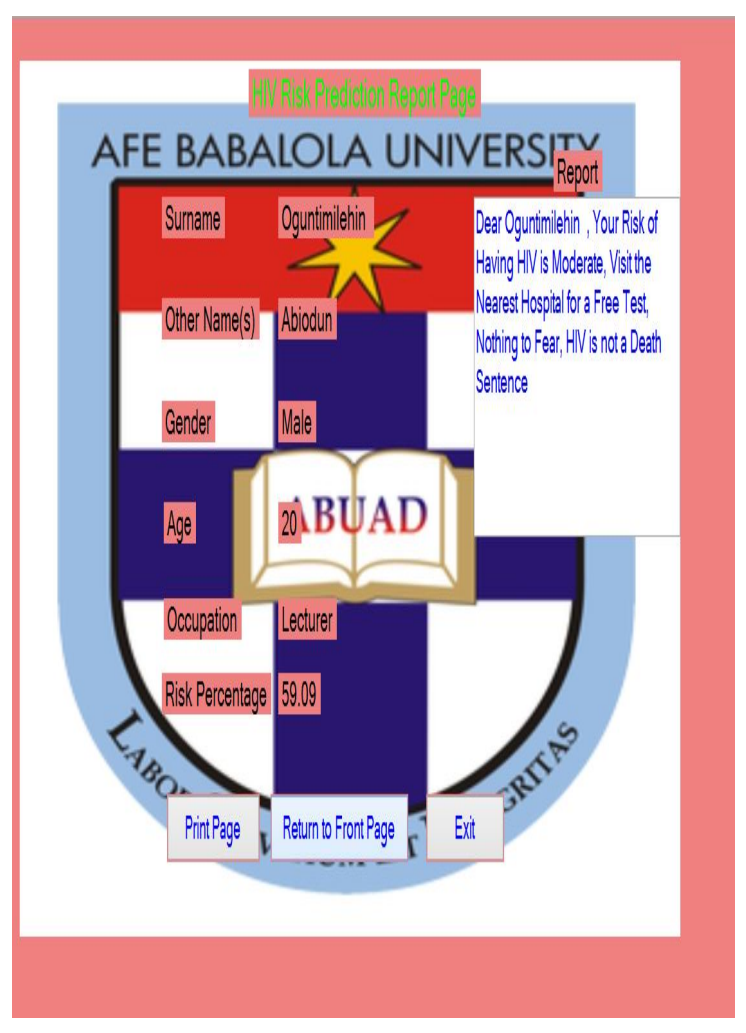

Figure 5: Screenshot of HIV Risk Prediction/Result Page

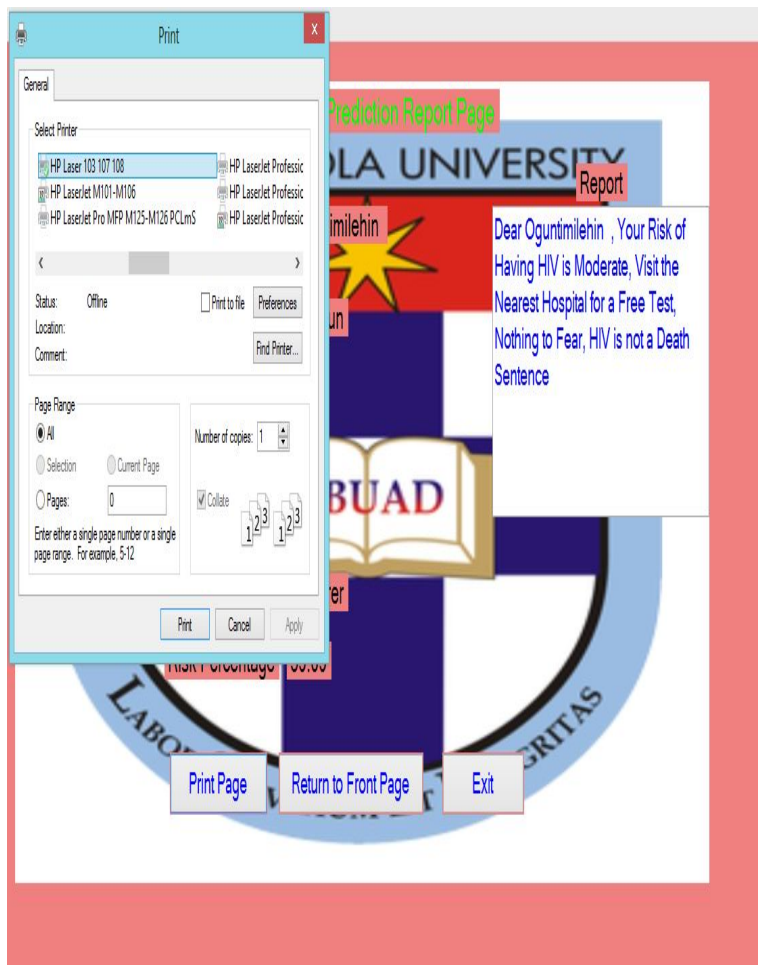

Figure 6: Screenshot showing user's opportunity to print the result 
Oguntimilehin A et al., International Journal of Science and Advanced Information Technology, 10 (6), November - December 2021,25 - 29

\section{CONCLUSION}

This research highlighted the fact that stigmatization is a primary barrier to initial and continuous HIV testing even among individuals living in high risk areas. This has engendered potentially dangerous habits like unwillingness to undertake HIV tests, non-disclosure of HIV status. These have in turn affected linkage to HIV care, uptake of HIV antiretroviral therapy, and medication adherence, particularly among vulnerable populations that are at the greatest risk for HIV infection; and more so contributed to the spread of the disease. We strongly argue that stigmatization will not be an issue for individuals who undertake their initial HIV evaluation with the use of this application. More so, the system has been designed to give appropriate advice depending on what output the user gets. The system also strongly advocates an actual blood test for HIV as it is the only way the HIV status of anyone can be confirmed.

\section{REFERENCES}

1. J. Daniel Kelly, Sheri D. Weiser, Alexander C. Tsai (2015), Proximate Context of HIV Stigma and Its Association with HIV Testing in Sierra Leone: A Population-Based Study, Springer Science \& Business Media, New York, DOI: 10.1007/s10461-015-1035-9.

2. M. Gwadz, N.R. Leonard, S. Honig, R. Freeman, A. Kutnick and A.S. Ritchie. Doing battle with "the monster": How high-risk heterosexuals experience and successfully manage HIV stigma as a barrier to HIV testing, International Journal for Equity in Health, 17:46.2018,https://dx.doi.org/10.1186\%2Fs12939-0180761-9

3. O.T. Agbonifo and O.R. Akinyede. Modelling A Frame Work For Telemedicine in Transmitting Medical Data For Diagnosis Management in Nigeria, in Nigeria Computer Society $22^{\text {nd }}$ National Conference. 325-332, 2008

4. A.A. Awofala, O.E. Ogundele, O.E, HIV epidemiology in Nigeria. Saudi Journal of Biological Sciences (2016), http://dx.doi.org/10.1016/j.sjbs.2016.03.006

5. J.A. Belle, N.N Gamedze, Behavioural Factors Contributing to the Transmission of HIV and AIDS amongst young women of Mbabane in Swaziland. Afri Health Sci. 2019;19(3):2302-2311. https://dx.doi.org/10.4314/ahs.v19i3.2

6. J.J Eze,. Modeling HIV/AIDS Epidemic in Nigeria, Ph.D. thesis, 2009, University of Glasgow. Available:<http://theses.gla.ac.uk/642/1/2009EzePhD.p df $>$, accessed 15/07/2021.

7. Federal Ministry of Health. HIV Integrated Biological and Behavioural Surveillance Survey 2010. Federal Ministry of Health, Abuja, Nigeria, 2010, Available: <http://www.popcouncil.org/pdfs/, accessed 14/06/2021.
8. Joint United Nations Programme on HIV and AIDS. Global Report: UNAID Report on Global AIDS Epidemic, 2012, UNAID.

9. G. Maitrayee, ICT and AIDS literacy: A challenge for information professionals in India Article in Program Electronic Library and Information Systems, May 2007. DOI: $\quad 10.1108 / 00330330710742917, \quad$ accessed $12 / 04 / 2021$.

10. NNACA, 2015 Reports on AIDS. Nigeria National Agency for the Control of AIDS, 2015.

11. C. Nyasulu, and W.D. Chawinga. The Role of Information and Communication Technologies in the Delivery of Health Services in Rural Communities: Experiences from Malawi, South African Journal of Information Management 20(1), a888. https://doi. org/10.4102/sajim.v20i1.888), accessed 15/01/2021.

12. A. Oguntimilehin. A Mobile Malaria Fever Clinical Diagnosis System Based on Non Nested Generalized Exemplar (NNGE), International Journal of Emerging trends in Engineering Research, vol. 8, No.2, pp. 259-264, 2020. https://doi.org/10.30534/ijeter/2020 103822020

13. A. Oguntimilehin A, A.O. Adetunmbi, and K.A. Olatunji. A Machine Learning Based Clinical Decision Support System for the Diagnosis and Treatment of Typhoid Fever, International Journal of Advanced Research in Computer Science and Software Engineering, Vol. 4 issue 6, June, 2014, pp. 961-969

14. M. Shekar and K. Otto. ICTs for Health in Africa, accessed 17 April, 2021, from http://siteresources .worldbank.org/extinformationandcommunicationandte chnologies/resources/ 282822-1346223280837/Health.pdf

15. T Sørensen et al. Tove Sørensen*, Ulrike Rivett $\dagger$ and Jill Fortuin $\neq$ HIV/AIDS in South Africa, Journal of Telemedicine and Telecare 2008; 14: 37-41 DOI: 10.1258/jtt.2007.070502

16. UNAIDS, MEETING REPORT 2016: Information and communications technologies Engaging the private sector and communities in HIV programmes with gay men and other men who have sex with men, UNAIDS, 2016.

17. UNAIDS NIGERIA, WHO Reports, National Agency for the Control of AIDS (NA,NIGERIA)/World Health Organisation Report, WHO, , https://www.unaids.org /sites/default/files/20190314PRNigeriaen.pdfWHORepo rts, accessed 27/05/2021.

18. UN/WHO, WHO guidance on Artificial Intelligence to improve healthcare, mitigate risks worldwide, 2021, https://news.un.org/en/story/2021/06/1094902, accessed 22/07/2021.

19. A. Nasidi and T.O. Harry. The epidemiology of HIV/AIDS in Nigeria. In: Adeyi, O., Kanki, P.J., Odutolu, O., Idoko, J.A. (Eds.), AIDS in Nigeria: A Nation on the Threshold. Harvard Centre for Population and Development Studie, Cam bridge (Massachusetts). 